2. Beauchamp TL, Childress JF. Principles of Biomedical Ethics. 7th ed. Oxford, UK: Oxford University Press; 2013:250-301.

3. Daniels N. Accountability for reasonableness. BMJ. 2000;321:1300-1.

4. Gibson JL, Martin DK, Singer PA. Evidence, economics and ethics: resource allocation in health services organizations. Healthc Q. 2005;8:50-9. 4.

5. Phelps CE, Lakdawalla DN, Basu A, Drummond MF, Towse A, Danzon PM. Approaches to aggregation and decision making-a health economics approach: an ISPOR Special Task Force report [5]. Value Health. 2018;21:146-54.

https://doi.org/10.1016/j.jtcvs.2018.10.105

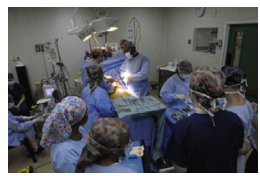

\section{PROCESS IS \\ HELPFUL, BUT THE \\ PROCUREMENT \\ PROBLEM PERSISTS}

\section{Reply to the Editor:}

We are grateful to Tam and colleagues $^{1}$ for identifying process as important in resolving disagreements between surgeons and administrators. We suggest that such collaborative efforts would be most productive if guided by prospectively defined, well-formatted, ethically sound, generally accepted processes, through which disputes between hospital administration and physicians can be justly adjudicated.

Daniels' framework, ${ }^{2}$ executed through multicentric decision analysis, ${ }^{3}$ may offer a suitable pathway to prevent or resolve serious and often emotional disagreements. We thank Tam and colleagues ${ }^{1}$ for noting these approaches.

We have a caveat, however, related to our vignette describing a surgeon's dilemma. ${ }^{4}$ Such a sophisticated collaborative process may be followed and may include input from our hypothetical surgeon, but if a conclusion is reached that is contrary to the surgeon's input, and she cannot with integrity implant an alternative heart valve that she believes, in her heart of hearts, to be inferior to her own choice, what should she do then? We find ourselves right back where we started.
Authors have nothing to disclose with regard to commercial support.

Scott Millikan, $M D^{a}$

Gregory Trachiotis, $M D^{b}$

Robert M. Sade, $M D^{c}$

${ }^{a}$ Department of Cardiovascular Surgery

Billings Clinic

Billings, Mont

${ }^{b}$ Division of Cardiothoracic Surgery

Department of Surgery

George Washington University Medical Center Veterans Affairs Medical Center

Washington, DC

${ }^{c}$ Division of Cardiothoracic Surgery

Department of Surgery

Institute of Human Values in Health Care

Medical University of South Carolina

Charleston, $S C$

\section{References}

1. Tam DY, Wijeysundera HC, Fremes SE. Outcomes matter but processes may matter more in valve procurement. J Thorac Cardiovasc Surg. 2019; 157:e201-2.

2. Daniels N. Accountability for reasonableness. BMJ. 2000;321:1300-1.

3. Phelps CE, Lakdawalla DN, Basu A, Drummond MF, Towse A, Danzon PM. Approaches to aggregation and decision making-a health economics approach: an ISPOR Special Task Force report [5]. Value Health. 2018;21:146-54.

4. Millikan S, Trachiotis G, Sade RM. Should a surgeon comply with hospital administration's demand to change valve preference? J Thorac Cardiovasc Surg. July 28, 2018 [Epub ahead of print].

https://doi.org/10.1016/j.jtcvs.2018.10.122 